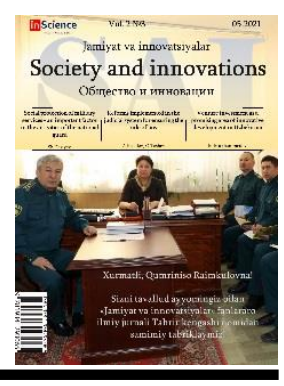

\title{
Civil law problems of constituent contracts
}

\section{Vokhidjon TOPILDIEV ${ }^{1}$}

National University of Uzbekistan

\begin{tabular}{l} 
ARTICLE INFO \\
\hline Article history: \\
Received April 2021 \\
Received in revised form \\
20 April 2021 \\
Accepted 15 May 2021 \\
Available online \\
15 June 2021 \\
\hline Keywords: \\
legal entity, \\
foundation agreement, \\
charter, founders, \\
general meeting of founders, \\
contract on joint activity, \\
contract accession, \\
company, corporate relation, \\
civil organizationally legal \\
relation, civil legislations.
\end{tabular}

\begin{abstract}
In this article, the author provides a scientific assessment of the history of the conclusion of constituent agreements on the creation of legal entities, based on the Roman, former Union and civil law of the Republic of Uzbekistan, and also theoretically and practically analyzed the essence of constituent agreements and their types on the basis of current legislation. He also proposed to include in the Civil Code of the Republic of Uzbekistan a separate special chapter regulating constituent agreements.

2181-1415/C 2021 in Science LLC.

This is an open access article under the Attribution 4.0 International (CC BY 4.0) license (https://creativecommons.org/licenses/by/4.0/deed.ru)
\end{abstract}

\section{Таъсис шартномаларининг фуқаролик хуқуқий муаммолари}

\footnotetext{
Калит сўзлар:

юридик шахс,

таъсис шартномаси,

устав,

муассислар,

муассисларнинг умумий йиғилиши,

биргаликдаги фаолият

шартномаси, шартномага

қўшилиш,

жамият,

корпоратив муносабатлар,

фуқаролик ташкилий-

хуқуқий муносабатлар,

фуқаролик қонунчилиги.
}

\begin{abstract}
АННОТАЦИЯ
Муаллиф мазкур мақолада юридик шахсларни ташкил этиш бўйича таъсис шартномаларининг тарихига Рим хуқуқи, собиқ иттифоқ даври ва Ўзбекистон Республикаси фуқаролик қонунчилиги асосида илмий бахо берган хамда таъсис шартномаларининг мохияти уларни турларини амалдаги қонун хужжатларига асосланган холда назарий ва амалий жихатдан тахлил этган. Шунингдек, Ўзбекистон Республикасининг фуқаролик кодексига таъсис шартномаларини хуқуқий тартибга соладиган алохида махсус боб киритишни таклиф қилган.
\end{abstract}

\footnotetext{
${ }^{1}$ Candidate of juridical sciences, Ass. Professor of department "Civil society and legal education", National University of Uzbekistan. Tashkent, Uzbekistan.

E-mail: vtopildiev@mail.ru.
} 


\section{Гражданско-правовые проблемы учредительных договоров}

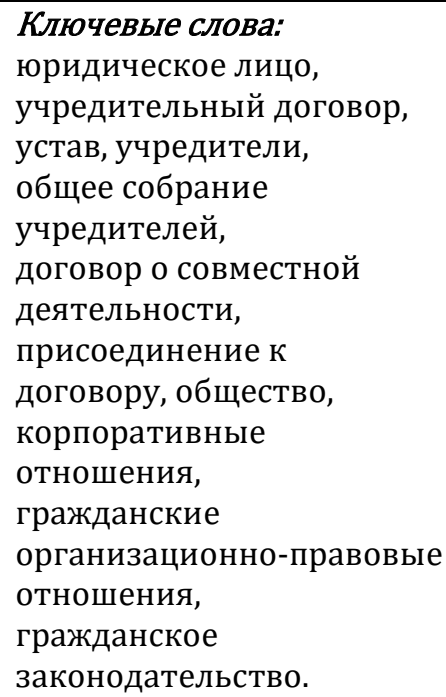

\section{АННОТАЦИЯ}

В данной статье автор дает научную оценку истории заключения учредительных договоров о создании юридических лиц, на основе римского, бывшего Союза и гражданского права Республики Узбекистан, а также теоретически и практически проанализировал сущность учредительных договоров и их виды на основе действующего законодательства. А также предложил включить в Гражданский кодекс Республики Узбекистан отдельную специальную главу регулирующую учредительные договоры.

\section{INTRODUCTION}

Founding agreements on the establishment of a legal entity have certain historical roots on its origins. If we look at Muslim right, joint work on Muslim law is differentiated as a form of partnership, business, and activity. Even the Muslim right, the common law of patriarchal law, which existed before Roman law, was also regulated. For example, before the birth of the Muslim right, our Prophet Muhammad Sallallahu al-Wassalam agreed to work together with Khadija, one of the richest city of Mekke. According to her, Khadija prepares goods and caravans for sale. Muhammad alaihiss-salam had to sell these goods to Syria (Syria). The resulting profit will be distributed equally in earnings. In general, although joint activities are not defined in the customary law or in the Muslim right, there are certain rules governing it and widely used. The roots of the founding agreement have been manifested in the creation of partnerships for long-term partnerships in order to carry out joint activities by partners in order to promote trade and craftsmanship in Rome. With the development of commodity turnover, such trade and craftsmanship companies have to have their own property, which became apparent to the extent that the property was distinct from the other property of the partnership. There has also been a need for the existence of a company and the need for sustainability, regardless of the company's staff and stakeholders. Thus, in the course of the principle of the Roman right, certain types of companies (bankers, traders, etc.) began to be recognized as legal entities.

\section{MATERIALS AND METHODS}

In the XIII-XIV centuries contracting business associations were formed in Western European countries as a shareholder company. For example, in 1673, the French Trade Regulation stipulates the establishment of a legal entity on a contractual basis in the form of a wholly-owned subsidiary. It is expected that its members will be jointly liable for the obligations of the company. In medieval times, agreements on the creation of a company in the field of maritime sales (as a specific past-acquainted commanctist company) have been widespread. This agreement was a foundation agreement on its content.

In Russia, facility agreements have been specially created. According to the manifesto dated 1 January 1807 of the Russian Emperor Alexander I, traders were advised to carry out their trade through merchant bargains. When Russian laws codified, the partnership agreement was incorporated into a 
set of civil rights (Articles 2132-2133) and Commercial Charter (article 63.67). Soon in the legal science and legal doctrine, such contracts began to be called founder or founding agreements.

After the annexation of the majority of the territory of Uzbekistan into Russia, the Russian civil law was applied in certain areas in these areas. Under the founding agreements, trading companies have begun to form. At the beginning of the 20th century there were hundreds of trade associations in the Turkestan General Governorate, as well as in Khiva Khanate and Bukhara Emirate. And most importantly, local communities were actively involved in the activities of these companies. For the same reason, it is not a mistake to say that founding agreements on the territory of the country began to be used in the late 19th century. After the October Revolution, the joint operation and the establishment of associations did not stop at once. Accordingly, the New Economic Policy, that is, in the NEP periods (from the beginning of the 20th century), the commodity turnover has been driven by small businesses. Thus, the first civil code adopted in the Soviet era - the Civil Code of the RSFSR of 1922, although the term "founding agreement" was not used, was the order of conclusion of contracts, partnerships, partnerships, limited liability partnerships. (Article 295-321 of the RSFSR Civil Code). As it is known, the full text of the RSFSR Code of Civilization from the end of the 1920s was legally valid as the Uzbek SSR Civil Code. It is important to note that this Code was practiced until the early 1960s, when it was formally taken, that the founding treaties had a long legal basis in the soviet legal system. However, in practice there was no possibility to create any kind of company. Particularly, it was not possible to establish associations based on founding agreements in the field of commercial enterprise. Creation and attraction of such a company could at least be condemned as bourgeois private property, and even founders of the partnership could be subject to criminal liability as a private entrepreneur. Citizens of the USSR and the Union of Soviet Socialist Republics, adopted in the early 1960s, and the Civil Code of the Uzbek SSR, developed on its basis, did not envisage provisions on founding agreements based on ideological beliefs. As you know, the Soviet Union began to suffer a deep economic downturn in the late 1970s and early 1980s. An attempt to overcome this decline has resulted in various economic reforms. In particular, efforts were made to improve the co-operative movement, the management of stateowned enterprises, and to enhance the interests of the structural subdivisions of enterprises based on internal economic accounting. At the same time, positive shifts have taken place with the establishment of joint ventures with foreign partners. It was in the midst of the 80s that the founding agreements returned to the legal arena. In other words, government agencies and foreign partners have started to form joint ventures under a founding agreement. However, normative documents still did not have provisions on founding agreements. The founding agreement was first mentioned in the $1980 \mathrm{~s}$ when creating joint ventures. On May 25, 1991, Article 13, paragraph 2, of the Civil Procedural Code of the Union of Soviet Socialist Republics, for the first time, legal foundations of constituent contracts were given. Under the constituent agreement, the founders undertake to establish a legal entity, establish the procedure of joint activities for its creation, the transfer of its property and its participation in its activities. The procedure for the distribution of profits and profits among the participants, the regulation of the activities of the legal entity, the procedure and conditions for the exit of the founders (participants) shall be determined on a contractual basis. Later, in the civilian codes of the CIS countries, there was a norm in the content of the founding agreement.

If we look at the nature of the founding agreement, then this contract is a specific type of contract of joint activity. In general, the term of validity of this agreement seems to be related to the occurrence, registration or operation of a legal entity. In fact, this is not the case, as it is rightfully stated in the literature, that it will have legal force at the conclusion of this agreement, create rights and obligations between the parties, and the parties will act on its implementation. However, there are situations in which one can mislead: when a foundation agreement is transferred to a competent public authority 
for registration of a legal entity as a constituent document, it must be notarized. This requirement is based on the Resolution of the Cabinet of Ministers of the Republic of Uzbekistan from August 20, 2003 of No. 357 "About perfection of system of the state registration and accounting of business entities" It is set out in paragraph 11. According to it, two original notarized constituent documents for registration of entrepreneurship entities as legal entities should be submitted. In paragraph 8 of this Regulation, the founding agreement for the additional liability companies and the charter capital for limited liability companies, and only for limited partnerships, constituent agreement is a constituent document issued by the business entity (legal entity) to the registering authority. Such a notarial certification, in fact, does not have a material effect on the actual validity of the foundation agreement. Before founding a founding agreement by the founders, before carrying out the notarial certification, at least the following actions must be taken to implement this agreement:

a) holding a general meeting of founders;

b) registration of documents required for registration of a legal entity;

c) participation in the financial costs required for registration;

d) Participation in formation of the authorized fund of a legal entity.

By doing so, the parties are bound to comply with the terms of the founding agreement. This means that the form of the contractual agreement is sufficient to have a simple written form. However, the implementation of the terms of the contract can be considered as a ground for finding and terminating the contract as invalid in the subsequent stages of the contract. In other words, the legal entity registrar does not have the right to accept a founding agreement in a simple written form, and the parties are obliged to certify the foundation agreement notarial. Otherwise, even if there is no reason to conclude that the founding agreement is invalid, in practice the termination of the founding agreement is suspended. Thus, the idea that the form of the facility agreement is simple should be controversial. The format of the constituent agreements varies by two stages:

a) The first stage is the stage of preparation for the formation of a legal entity. This is a simple written form;

b) The second stage is the registration of the legal entity and its establishment. At this stage, the contract for establishing a legal entity must be observed.

Besides, founding agreement is subject to state registration is also controversial. There is no direct reference to the current legislation on the state registration of founding agreements. On the contrary, it is about state registration of a legal entity, which is based on the founding agreement. In general, the literature deals with the fact that these features of the founding agreement have an impact on the functions of the founding agreement. "The constituent agreement defines the obligations of its constituents to establish a legal entity, to form its charter capital and to pay part of it before the registration of a legal entity. Thus, the terms of joint venture arrangements prior to the registration of a legal entity become effective as of the date of the foundation agreement. At this stage, the founding agreement creates a commitment relationship between its participants. Consequently, the founding agreement carries out the function of regulating the obligations of the founders on the establishment of a legal entity. The provisions of the constituent agreement are executed and the state registration of a legal entity creates a set of rights and obligations between the founders of the legal entity and the founding agreement, as well as the participants themselves. This set of rights and obligations constitutes the content of relative legal relationships and therefore does not constitute a liability relationship. In other words, these relative legal relationships are corporate relationships. For this reason, regulation of corporate legal relations is a function of a constituent agreement after the state registration of a legal entity. For example, the founding agreement for the establishment of a limited liability company establishes the subject and goals of the company. Generally, all the essential terms of the founding 
agreement are fully applicable to the legal status of a legal entity. Obviously, it is part of corporate law relations. According to N. Suvorov, the institutional arrangement of the institutional arrangement of the constituent agreement is reflected in the legal relationships of these relations.

Corporative legal relationships are a complex structured consisting of the following elements: (founders)

a) Legal relations between the corporation (legal entity) and its separate participants

b) Legal relationships between the individual participants (founders) of the corporation (legal entity)

In these relationships, the participants of corporate relationships are owners of both property and non-owners.

It may be said that corporate relationships arising between the parties to the founding agreement lie in relation to a legal entity (corporation), corporate governance relationships. Of course, corporate governance and simple corporate relationships are relatively new social phenomena for the civilization of our country. He is currently being studied and analyzed by economists, philosophers, sociologists, political scientists, and financial experts. Without undermining the research carried out by them, it should be acknowledged that corporate relationships are legal in nature and can only be disclosed only for legal investigations on the essence and content of these relationships. The researchers are paying particular attention to the issue of institutional arrangements and corporate relationships. For example, prof. G. Polkovnikov writes: "There are serious problems with the establishment and registration of joint-stock companies, which is why the legal nature and nature of the constituent agreement on the establishment of an open joint-stock company has not yet been properly studied. What is the legal nature of this agreement? In essence, it is a joint venture agreement, the difference is that the participant of a legal relationship does not have to be an entrepreneur, and if the participant's share of the joint venture's liability is determined, the founding agreement establishes a joint responsibility of the participants. However, the joint responsibility of the participants is determined prior to the state registration of the Joint-Stock Company. At the same time, the founders of the company can approve the joint-stock company's agreements before the registration, in which the responsibility is borne by the Joint-Stock Company. In other words, the Joint Stock Company is the debtor of the transactions made by the founders. This is a Russian law. In the United Kingdom, the procedure for approving the responsibility of the founders before the Joint-Stock Company and the approval by the company of transactions made by them. This means: the company is not responsible for transactions between the founders before the company becomes a corporation. Only those who have signed the agreement will be liable for these transactions. Thus, the founders are personally responsible for the transactions they make, not only civil law but also criminal law, if the company wishes to take responsibility for the agreements and contracts concluded by the founders, then he must make a new contract on his behalf. Even if the founders have signed a contract with the company, the founders will not be liable for the company, even if the company receives profits and revenue as a result of this agreement. If an agreement is made for the benefit of the company and the company is expected to become a party to the transaction in the future, an agreement will be drawn up and the company will be listed as a party. Upon the registration of the company (after registration), a contract is concluded based on the internal procedures. It should also be noted that the role and importance of the constituent assembly in the charter capital is unstable. For example, in Russia, the Council of Ministers Decree on Joint-Stock Companies stipulates that the Charter is the founding document of the joint venture. Later such norm was annulled and the founding agreement was valid until the state registration of the jointstock company. This arrangement can be observed in almost all CIS countries. In this regard, it is worth noting how the practice of developed countries has been arranged. For example, there are two types of 
foundations in the joint-stock company: - This is a regulator regulating the external relations of the company and regulating internal relations. Sometimes they accept them as the only two-piece document. Instead of a memorandum in a joint-stock company, the charter is also adopted, and there is also a corporation regulation. The only constituent document for European countries is the charter of a joint-stock company. In order to better understand the functions of the constituent agreement, it is necessary to analyze the mechanism of influence on legal relations in the course of implementation of constituent agreements. Until now, the difference between the legal arrangement and the impact on the property before and after the state registration of a legal entity is under the founding agreement. If the foundation agreement is the only legal basis for the establishment of the founding party, the legal effect of the founding agreement will be cut in the next stage, since the legal entity will register its registration after its registration. The Charter is also a major source of legal regulation of legal entities and regulates some of the relationships between the participants (founders). So, after the state registration of a legal entity, the founding agreement will fall into the second plan (with the exception of full and limited partnerships, which is the founding agreement of the founding agreement). Even in some cases, the founding agreement is virtually irrelevant. For example, a well-known civic scientist, E. Sukhanov, examined the importance of the founding agreement on joint-stock companies, with great pleasure, "Unless the joint-stock company becomes a state-owned entity and becomes a legal entity, it remains the basic constituent document regulating the life of a joint-stock company. Moreover, after the sale of shares of the joint-stock company, the shareholders are created and they are considered as the principal subjects in the management of the joint-stock company. Consequently, neither the founding agreement nor the founders are required in such circumstances. Their existence can only be caused by excessive disagreements between shareholders and founders. Thus, the corporation was saying that the founding agreement system should be removed from the founding agreement. J.Yuldashev, a researcher, also argues that the founding agreement should be valid until the state registration of a jointstock company, and then to suggest that it is desirable to lose its legal force.

Indeed, are the main subjects of the management of a joint-stock company. In this case, founders of a joint-stock company become more and more subjects. This situation arises from the moment when the joint-stock company is fully formed and operating. After the state registration of a joint-stock company, there is no firm belief that all shares are considered stable and permanent subject until the sale of the shares (ie shares worth $\$ 50,000$ ), which should be considered as a joint-stock company. It is well known that the stock market may not be fully realized. If there is no demand for shares in the stock exchange and if it is not realized within one year, then the founders may file a lawsuit on the forced purchase of shares or the cancellation of the joint-stock company. In such cases, naturally, the founding agreement and the position of the founders are raised to the foreground. In other words, the founders assume full responsibility for the preservation or termination of the legal entity. The actions of the founders will continue to be regulated by the founding agreement. Consequently, the founding agreement retains its legal force.

Consequently, the concepts that the founding agreement should abolish after the establishment of a joint stock company can be considered as inappropriate and practically inappropriate.

In our opinion, to abandon constituent collective bargaining agreements is not quite correct. In most cases, the constituent agreement remains an essential part of the overall situation, unless the charter capital is fully stocked and it does not apply to the foundation agreement in the normal course of business. From the above, it can be concluded that a separate type of founding agreement is valid for a corporation.

The main type of constituent agreement is the constituent agreement of the general partnership and limited partnership. Such a foundation agreement is the sole and only founding certificate for a legal 
entity. The fact that there is no charter for these types of legal entities is determined by their essence. In other words, the activity of a legal entity is fully compatible with the work of its participants. The Law on Economic Partnership does not stipulate the principle that a partnership is a separate management body. This also indicates that the founding agreement is of particular importance to farmers.

Another type of constitutive agreement is a founding agreement, which is a legal entity that is in effect in parallel with its charter. It includes founding agreements with societies with limited liability and additional liability companies, joint ventures. Finally, after the state registration of a legal entity in the system of founding agreements, it is worth mentioning the above-mentioned points about the existence of founding agreements that do not have a direct involvement in the legal regulation of the relations with the legal entity.

\section{RESULTS AND CONCLUSION}

Thus, there are three types of founding agreements in the system of founding documents of commercial legal entities. They can be conditional on their characteristics as follows:

a) Monotown contracts that are the only constituent agreement as constituent documents;

b) "Equal Power Contracts", which are parallel to the constituent agreement and the Charter;

c) limited "discrete" facility agreements with practical legal arrangements.

For the purpose of this type of constituent agreements, the legal effect of their power is justified. However, this did not reflect the legal provisions. This does not allow taking into account the individual characteristics of the founding agreement. Therefore, it would be expedient to take this into account when improving legislation. Another type of constitutive agreement is founding agreements on the establishment of non-commercial legal entities. Foundation agreements are not applicable to all nonprofit entities. For example, a founding agreement does not apply to political parties, trade unions and similar structures. Generally, the founding agreement is always the first step in the process of establishing a legal entity. In some non-commercial structures, this task is carried out by initiative groups. The members of the Initiative Group are engaged in the establishment of a non-commercial legal entity and acquire the status of its members after the formation of a legal entity. If a non-profit organization is based on membership, then there will be specific relationships between founders (members of the founding agreement) and members.

It may be said that founding agreements on the establishment of non-profit organizations constitute a separate category of contracts in such a category. Article 16 of the Law on NonGovernmental Non-Profit Organizations of April 14, 1999 establishes constituent documents of nonstate non-profit organizations. It indicates that the constituent agreement made by the participants and the constituent union, which they have approved, constitute a constituent document. In the constituent agreement parties (founders) undertake to form an association (NGO) of non-state non-profit organizations, establishing the conditions for joint operation in the field of its creation, in order to provide it with its property and to participate in its activities, to manage the activities of nongovernmental non-commercial organizations, and to leave the fund of its founders. Other terms may also be included in the foundation agreement upon the agreement of the founders. Associations (unions) of non-governmental non-profit organizations may be established at least at the initiative of at least two nongovernmental nonprofit organizations. Article 25 of the Law on Non-Governmental NonProfit Organizations specifies the grounds for refusing the state registration of a non-state non-profit organization. A certain part of these principles relates to the contents of the constituent documents. In other words, it can be said that the law is reflected in the terms and conditions of the founding agreement. If the constituent agreement stipulates forcible change of the Constitution of the Republic of Uzbekistan, undermine sovereignty, integrity and security of the Republic of Uzbekistan, discrimination 
against the constitutional rights and freedoms of citizens, propaganda of social, national, racial and religious hatred, infringement on the health and morality of the citizens, or the state registration of a non-governmental non-profit organization may be refused, if it is foreseen for the establishment of militarized associations. Also, the name or symbolic features of a non-governmental non-profit organization are denied the state registration of a legal entity, even if it involves a state of national spiritual or religious affiliation. The constituent agreement is formed primarily by the establishment of the Association of Legal Entities (Union). As you know, there are currently many types of associations and unions of legal entities. This includes:
a) concerners;
b) associations;
c) federations;
d) condominiums and so on.

The concept of a constituent agreement is also interpreted differently by different authors. For example, I. Elishev establishes a foundation agreement - a consensual civil-law agreement regulating the relations arising between the founders (founders) during the establishment and operation of a legal entity. In his view, the founding agreement can be viewed as an example of a simple company (joint venture agreement). N.K. Kozlova assumes the founding agreement as a separate type of contracts. Even though Pukeuku Suhanov does not try to make a definitive description of the founding agreement, it may be understood that he joined the ideas of N.V. Kozlova about the essence and legal nature of the founding agreement.

In Article 43, Part 5 of the Civil Code of the Republic of Uzbekistan, there is no concept of a founding agreement. However, in this provision the main features of the founding agreement are disclosed. Charter),

Firstly, the founding agreement of a legal entity is compiled by its founders (approved by the

Secondly, the founding agreement is valid for third parties from the moment of its state registration (but not until then, it creates rights and obligations for founders participating in the contract only). Both features are set out in Part two of Article 43 of the FCC. The founders, if the third party is to sign the founding agreement, should also bear in mind the consequences of filing these conditions. Even if subsequent amendments to the founding agreement have been denied by the competent state authorities, the founders should act accordingly, even if the third party has followed them. Therefore, Article 43, Part 6 of the Civil Code stipulates that legal persons and their founders have no right to make such changes in their relationship with the third party acting in accordance with the founding agreement.

Another feature of the constituent agreement is the possibility of changing the scope of the parties to this agreement during the validity period of the contract. For example, a full-time company may have up to 50 members. It may be considered natural that the number of participants increases or decreases. Most importantly, the contract participants must be no less than two and must not be more than the maximum number of founders of a constituent agreement for a particular type of legal entity.

On the other hand, the inclusion of other participants in the original draft of the founding agreement seems to be the sign of the agreement. However, it should not be forgotten that a merger contract has been formulated by one of the parties in formulas or other standard forms, and the other party shall be formed only in the event that it is possible to accept the proposed contract entirely. In other words, it does not take part in forming contract forms. Only approval will be added (with the will and will of his own will). This is due to objective circumstances. This agreement is different from the individual contracts that all the terms of the contract are always negotiated by consensus. The accession 
agreement is slightly different from the general suitability of contracts. However, the lack of active participation of the Contracting Party in the formulation of the terms of the contract does not infringe its interests. On the contrary, Article $360 \S 2$ of the Civil Code sets out the circumstances that the complainant has the right to request for amendment or cancellation of the terms of the contract. Of course, the founding agreements are always included in the group of contracts, which are individually developed. However, according to the circumstances, the founders may require ultimatum to the new member or to agree to the terms of the contract unconditionally or incomplete negotiations. If a contracting party or companion is required to enter into a contract, the founding agreement may become an agreement.

In such a case, the Contracting Party shall have the right to demand that, under Article 360 of the Civil Code, its interests be protected.

It should be noted that the types of facility agreements may also include a specific facility agreement. Interestingly, the law does not call it a contract. Article 14 of the Law of the Republic of Uzbekistan "On public funds" of 29 August 2003 lists the documents required for state registration and registration of public funds. According to him, the following documents are submitted to the registering body for state registration of the fund:

- The application form with the surname, name, patronymic, year of birth and place of residence (postal address), signed by the founders or authorized by them;

- Information on the meeting (congress, conference) or the founders, the goals and objectives of the fund;

- A document confirming the initial funding of the fund.

In our opinion, these documents constitute an agreement of the original constituent agreement, even if it is specifically available. The main purpose of this agreement is to establish a public fund as a legal entity. After the formation of a legal entity, the previous agreement will be a historical stage and will have no regulatory impact on the future actions of the founders (joint participation in the activity of a legal entity) or on the future of a legal entity. The opinion of the founders on the mutual agreement, the contractual attitude of the parties is stated in the literature. For example, Y. Tursunov writes: Although the Law on the Agricultural Cooperatives of the Republic of Uzbekistan does not specify its constituent agreement, it must be noted that its founders should have a statement of the meeting on the establishment of a cooperative (shirkat xo'jaligi) stops. In addition, according to the Resolution of the Cabinet of Ministers of the Republic of Uzbekistan dated July 15, 1998 № 299 “On measures for the establishment of agricultural cooperatives (shirkats) in accordance with the legislation on agricultural reform", agricultural cooperatives (shirkats ) in the order of reorganization (Annex 2 of the decision) and the order of its decision making. That is, the founders have decided that a relevant decision should be taken. In our opinion, the founding of the founders of the agricultural cooperative on its establishment is in fact a multilateral foundation agreement. Among the scholars there is a point of view that is critical of this point of view.

The Strategies of Action in the five priority areas of development of the Republic of Uzbekistan in 2017-2021 set primary goals and objectives for liberalization of the economy, reducing state participation in regulation of economic relations, strengthening the protection of private property guarantees, encouraging entrepreneurship development and actively attracting foreign investment.

The Civil Code of the Republic of Uzbekistan (here in after referred to as the Civil Code), which is a codified law and determines the most important provisions of civil-law regulation, is a central place in the system of civil legislation documents.

The Civil Code of the Republic of Uzbekistan, adopted in 1995-1996, played an important role in civil-law regulation of the widespread transformation of the "transition period" and made it possible 
to create a solid legal basis for the development of market economy in the country. However, the analysis shows that the current version of the Civil Code does not adequately respond to the rapidly developing economic relations and international standards in the field of civil law. In particular:

Firstly, the Civil Code contains the legal form of legitimate legal institutions, as well as legal entities that are not part of the legal system of advanced economies based on market economy;

Secondly, there are no traditional civil-law institutions such as "commercial risk", "equality of business entities", "fair compensation", "refusal to perform contractual obligations";

Thirdly, in the modern market conditions, certain forms of civil-law contracts and relationships, including public-private partnership, dealer agreement, shareholder building, cluster production, ecommerce, crypto-currency turnover, privatization of land parcels and others not captured;

Fourthly, the existence of a large number of norms (about 80) in the Civil Code prevents the code from becoming a direct document and reduces its status in regulating civil-law relations;

Fifthly, the large number of organizational and legal forms of legal entities (for example, the law does not envisage the entry of other participants into a private enterprise or a unitary enterprise, which does not attract investors);

Sixthly, the Civil Code contains unreasonable restrictions on public law norms, private ownership and contractual relationships not related to civil law institutions;

Seventhly, the Civil Code does not contain rules governing the use of information and communication technologies in civil-law relations.

In order to achieve the goals and objectives outlined in the Action Strategy of the five priorities of the Republic of Uzbekistan for 2017-2021, as well as to bring the civil legislation into line with market economy and international standards,

1. Unification and systematization of the norms of the civil legislation;

2. Improvement of the basic civic and legal institutions;

3. Formation of sound legal basis for further development of the economy and attraction of foreign investments;

4. Introduction of innovative forms and procedures of regulation of civil-law relations, which are in high demand in modern conditions;

5. The Concept of Improvement of Civil Legislation of the Republic of Uzbekistan, which provides the expected outcomes of the Concept, as well as the main directions:

The third main direction of the Concept is the introduction of qualitative new mechanisms of contractual relations, including the optimization of types of contracts, the development of the initial contractual institute, the freedom of the contract, the stability of the contractual relationships, the regulation of the use of information and communication technologies in contractual relations; Inclusion of corporate relationships into the subject of regulation of the civil code, including the definition of peculiarities of activity of mass-stock companies, introduction of the "corporate contract", which is valid for corporate parties and obligatory for third parties, and the emergence of a corporate crisis it is necessary to pay special attention to the issues of determination of cutting mechanisms.

It is known that the founding agreement is part of corporate law relations. Therefore, in our opinion, in order to ensure the implementation of the tasks outlined in the Concept of the Civil Procedure of the Republic of Uzbekistan and further improve the corporate legal relations

First, theoretical and practical analysis of the doctrinal and legal definitions given to the founding agreement in civil law, legal literature and scientific research, the founding agreement is as follows: "The constituent agreement shall be signed by the founders on the basis of a compilation of a commercial, non- commercial or legal entity association, is an agreement on cooperation in the formulation of statutory funds, participation in the organization and management of its activities". push; 
Second, introducing a separate chapter into the constituent agreement of the current Civil Code of the Republic of Uzbekistan and introducing the concept of founding agreement, conclusion and cancellation of founding agreement, types of constituent agreements, such as monopoly contracts, equal installments, discrepancy agreements;

Third, while focusing on institutional relationships as the most important and fundamental part of civil-law relations today, there is a need for the separation of legal entities into corporate and noninstitutional legal entities and the identification of their legal status and activities in this context. It is important to adopt general principles that are inherent in corporate relationships and should apply to all corporations, and to state the basic provisions that are subject to separate laws on various types of corporations in the form of corporations, in the civil code of the Republic of Uzbekistan. This, in turn, requires the introduction of a separate section "Corporations" in the Civil Code of the Republic of Uzbekistan, which, together with clarifying the mechanism of civil-law regulation of organizational and legal relationships, contributes to its consistency and effectiveness.

\section{REFERENCES:}

1. Collecting the Government of the USSR. 1990. №15. - WITH. 82 Civil law. T, №2. - WITH. 333.

2. Polkovnikov G.V. Actual problems of Russian corporate law. -http // www. auditoriu.ru / books / 700 / Polkovnikov / http.

3. Eleshevich V.B. Legal entity, its origin and functions in Roman private law. St. Petersburg, (PP. 329-332), (PP. 451-454).

4. Bratus S.N. Subjects of civil law. M, Yur.lit, 1960. - P. 144.

5. Maslyaev I.A. Agreements on the establishment of joint ventures with foreign participation in the USSR. ISGIP. 1990. №2. (PP. 60-67).

6. Civil law. T, №2. - WITH. 333.

7. Suvorov N.S. On legal entities under Roman law. M, 1900. (PP.100-102).

8. Yuldashev J. Joint stock companies as subjects of civil law. 2004. - P. 67.

9. Civil law. P.1. M: Prospectus, 1996. (PP. 126-127).

10. Kozlova N.V. Constituent agreement on the creation of commercial companies and partnerships. M.: 1994. - P. 52.

11. The Decree of the President of the Republic of Uzbekistan "On measures to improve the civil legislation of the Republic of Uzbekistan" dated April 5, 2019, F-5464.

12. Law of the Republic of Uzbekistan "On Non-Governmental Non-Profit Organizations" of April 14, 1999. Bulletin of the Oliy Majlis of the Republic of Uzbekistan, 1996, No. 5, Article 115.

13. Law of the Republic of Uzbekistan "On public funds" of August 29, 2003. Bulletin of the Oliy Majlis of the Republic of Uzbekistan.

14. Tursunov Y. Civil legal issues of the formation and activity of agricultural cooperatives (shirkat xo'jaligi). Author's dissertation autobiography. T.: 2004. 